Agricultural Water Management xx (2012) xxx-xxx

Factors controlling sediment export in a small agricultural watershed

Agricultural Water Management xx (2012) xxx-xxx in Navarre (Spain)

R. Giménez*, J. Casalí, I. Grande, J. Díez, M.A. Campo, J. Álvarez-Mozos, M. Goñi

- The hydrological response of a small agricultural watershed was evaluated. $~$ Factors having a key influence on runoff and sediment production in a watershed were studied. $\triangleright$ Multivariate statistical techniques were applied for the interpretation of datasets. $>$ The soil humidity condition before the flow played a key role in the watershed behaviour. $>$ Significant differences between wet and dry season floods were evident.

(c) 2012 This manuscript version is made available under the CC-BY-NC-ND 4.0 license http://creativecommons.org/licenses/by-nc-nd/4.0 


\section{Factors controlling sediment export in a small agricultural watershed in Navarre (Spain)}

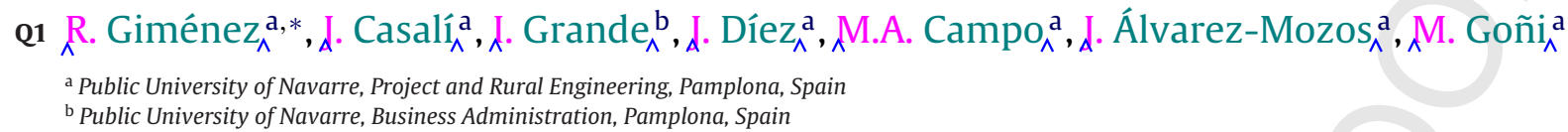

\section{A R T I C L E I N F O}

\section{Article history:}

Received 29 June 2011

Accepted 21 March 2012

Available online xxx

\section{Keywords:}

Runoff generation

Sediment production

Mediterranean condition

Hydrological response

Multivariate analysis

Hysteretic loops

\begin{abstract}
A B S T R A C T
It is recognised that the hydrological and erosion processes in watersheds are very much conditioned by the (inter)action of a number of variables. This paper covers a 15-year period of studying those factors that have a major influence on the sediment yield and transport during individual hydrological events in a small Mediterranean agricultural watershed. Multivariate statistical techniques such as cluster analysis and principal component analysis were applied for the interpretation of datasets. In addition, the relationships between suspended sediment concentration and discharge (hysteretic loops) were also analysed. The hydrological response of the studied watershed is mainly controlled by the antecedent condition of the flow. Most of the runoff and sediment are generated during the wet season when vegetation cover is scant and saturation overland flow occurs promptly as a response to almost any rainfall events. In contrast, during the dry seasons even if high-intensity rainfalls normally occur, very scant runoffs are, however recorded, at the exit of the watershed. Most of the eroded sediment seems to come from riparian areas. The discharge registered at the watershed outlet up to $1 \mathrm{~h}$ prior to the flood is a very good surrogate for antecedent soil moisture.
\end{abstract}

(c) 2012 Published by Elsevier B.V.

\section{Introduction}

It has long been recognised that agriculture is one of the main activities causing soil and water degradation worldwide (Montgomery, 2007). It is thought that a quarter of Europe's agricultural land exhibits some erosion risk (EEA, 2005).

The relationship between water discharge and sediment production in a watershed is largely affected by the climate conditions (Vega et al., 1998; Singh et al., 2004). Furthermore, this relationship can also show (important) seasonal variations as documented in many works (e.g., Gregory and Walling, 1973; Van Dijk and Kwaad, 1996; Steegen et al., 2000; Casalí et al., 2008, 2010).

Moreover, many studies have shown that there is a great variability in exported sediment yield from watersheds depending on the characteristics of the prevailing runoff-generating rainfall events (Seeger et al., 2004; Casalí et al., 2008; Fang et al., 2008; Salant et al., 2008; Soler et al., 2008). These characteristics depend on the (inter)action of different physical and anthropogenic factors controlling soil detachment and sediment transport in each event. Among these factors are: rainfall and discharge characteristics (Nadal-Romero et al., 2008), soil moisture and antecedent rainfall
(Seeger et al., 2004), land use (Casalí et al., 2010), soil surface conditions (Steegen et al., 2000), sediment availability (Regüies et al., 2000), distance between the sediment source and the watershed outlet (Steegen et al., 2000) and dominant sediment generating processes (e.g., sheet erosion, gully erosion) (Regües et al., 2000).

Furthermore, the relationship between discharge and sediment concentration is mostly not homogeneous during a single event leading to hysteretic loops. More precisely, Williams (1989) defined five common classes of hysteretic loops: single valued, clockwise, counter-clockwise, single valued plus a loop and eight shaped. This variation in the water discharge-sediment concentration relationship is often used to make inferences about the various processes contributing to the sediment export from a watershed (Jansson, 2002). For instance, a counter-clockwise hysteresis is often seen as an indication that most sediments are delivered by hillslope processes, reaching the watershed outlet during the falling limb of the hydrograph (Klein, 1984; Baca, 2008); whilst a clockwise hysteresis is interpreted as an indication that within-channel sediment sources and/or sediment flushing (i.e., the removal of sediment made available during interstorm periods) are prevailing processes (e.g., Regües et al., 2000; Zabaleta et al., 2007).

Therefore, a long-term analysis of the relationship between exported sediment, rainfall/discharge and antecedent conditions of the flow can help towards a better understanding of the hydrological and eroding processes within a watershed. In addition, this 

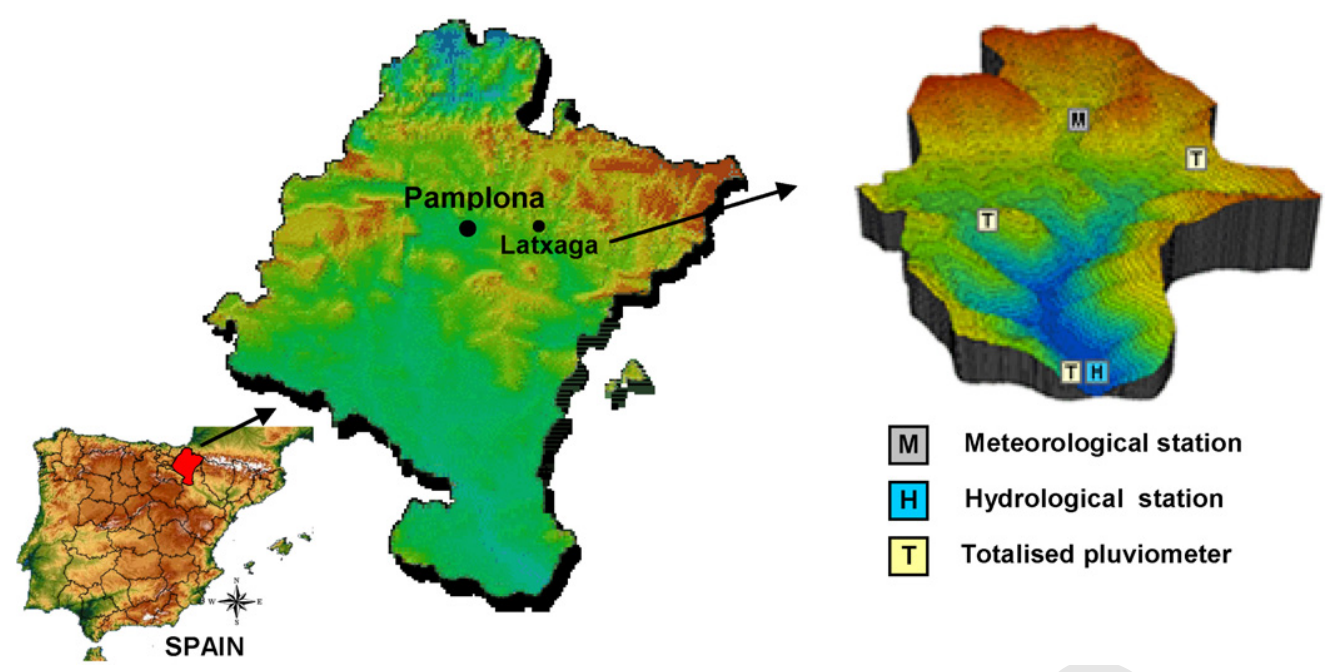

M Meteorological station

H Hydrological station

$\mathrm{T}$ Totalised pluviometer

Fig. 1. Laxtaga watershed is one of the experimental agricultural watershed of the Government of Navarre.

knowledge is highly relevant in the development and evaluation of models and the design of strategies for a watershed's sustainable management. However, the interpretation of this relationship is not a straightforward task due to the lumped nature of this approach (Slattery and Burt, 1997). Yet, sediment balance can be obtained with a reasonable precision in small watersheds $\left(<10 \mathrm{~km}^{2}\right)$, where the continuous monitoring of variables (e.g., turbidity) can be carried out with relative ease (Lorente et al., 2000). Besides, suspended sediment is the type of sediment that best facilitates a continuous study of the sediment/discharge relationship (Lorente et al., 2000).

Multivariate statistical analyses such as principal component analysis (PCA) and cluster analyses (CA) are mathematical techniques often used to study complex dataset. PCA enables relations among variables, whilst CA enables relations among samples to be interpreted in terms of simpler relations that provide an insight into the underlying structure of the dataset (Lambrakis et al., 2004). More precisely, these techniques allow one to obtain information about the similarities or dissimilarities between sampling sites, identification of variables responsible for spatial and temporal variations in the studied processes, and the hidden factors explaining the structure of the dataset (Shrestha and Kazama, 2007).

Multivariate statistical analyses are frequently applied to different problems in geological investigation, geochemistry, environmental geology, etc. (e.g., Vega et al., 1998; Lambrakis et al., 2004). However, the use of this type of statistical analysis is less common for evaluating the hydrological and sediment response to rainfall events in order to understand the watersheds dynamics and the main factors ruling the processes involved (e.g., Seeger et al., 2004; Nadal-Romero et al., 2008; Zabaleta et al., 2007; Raux et al., 2011). For instance, Zabaleta et al. (2007) analysed the behaviour of different watersheds - in the Basque Country, Spain - by using PCA. In one case, they found a strong correlation between precipitation and discharge but not between these variables and the antecedent conditions (flash flood events). Whilst in a different watershed they found no correlation between precipitation and discharge but a large one between discharge and antecedent conditions; this due to a higher regulation capacity of its soils. Likewise, Seeger et al. (2004) determined, by a similar multivariate analysis, that the average soil moisture was the main factor steering runoff generation and sediment transport in a small mediterranean watershed.

The aim of this study is to determine, in a small Mediterranean agricultural watershed, the factors that have a major influence on sediment yield and transport during individual hydrological events, and to analyse the link between rainfall, runoff and sediment export.
In this paper, a large dataset (rainfall, runoff, sediment) recorded at Latxaga grain-sown watershed (Navarre, Spain) during more than a decade of continuous monitoring are analysed using mainly multivariate statistical analyses.

\section{Materials and methods}

\subsection{Study area}

\subsubsection{Study watershed}

The Latxaga watershed (207 ha) is located in the central eastern part of Navarre (Spain) (Fig. 1). The geographical coordinates of the watershed outlet are $42^{\circ} 47^{\prime} 7.5^{\prime \prime} \mathrm{N}$ and $1^{\circ} 26^{\prime} 11.4^{\prime \prime} \mathrm{W}$. The main morphological characteristics of the watershed are shown in Table 1. Its climate is humid submediterranean, with an average annual precipitation of $835 \mathrm{~mm}$, distributed over 95-100 days of rainfall, and an average annual temperature of $12^{\circ} \mathrm{C}$ (Gobierno de Navarra, 2001). The valley bottom slopes are about $5-7 \%$, whereas the hill slopes can reach up to $30 \%$. Geologically, the area is underlined by clay marls and Pamplona grey marls (Gobierno de Navarra, 1997). The prevailing soil class is Paralitic Xerorthent covering $43 \%$ of the watershed, and located on eroded hillslopes; these soils are shallow (less than $0.5 \mathrm{~m}$ deep). Fluventic Haploxerept soils cover $36 \%$ of the watershed area, and are located on swales and hillslopes where eroded soil accumulates; these soils are deeper (over $1 \mathrm{~m}$ deep). The upper horizon of the predominant soils is silty-clay-loam with a D50 (median grain diameter) of around $0.01 \mathrm{~mm}$. However, and by minimising aggregate breakdown (Giménez et al., 2009), the corresponding D50 rises to $9 \mathrm{~mm}$.

Preliminary results from experiments carried out with a rain simulator indicate that the final infiltration rate of the soils ranged between 20 and $30 \mathrm{~mm} \mathrm{~h}^{-1}$, which is a much larger figure than expected from the predominant texture (i.e.,

Table 1

Some morphological characteristics of Latxaga watershed (after Casalí et al., 2008).

\begin{tabular}{lc}
\hline Morphological characteristics & Values \\
\hline Area $\left(\mathrm{km}^{2}\right)$ & 2.07 \\
Perimeter $(\mathrm{km})$ & 6.67 \\
Total channel length $(\mathrm{km})$ & 5.38 \\
Minimum elevation $(\mathrm{m})$ & 504 \\
Maximum elevation $(\mathrm{m})$ & 639 \\
Av. slope (\%) & 19.3 \\
Av. (permanent) channel slope (\%) & 12.4 \\
Drainage density $\left(\mathrm{km} \mathrm{km}^{-2}\right)$ & 2.61 \\
\hline
\end{tabular}




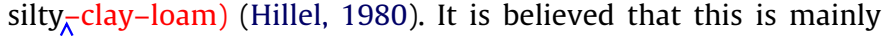
due to (bio)macropores and cracks present in the fields especially during summer.

The watershed is almost completely cultivated with winter grain (wheat and barley usually cover $80 \%$ or $90 \%$ of the total area). Tillage is conventional, and frequently parallel to contour lines. Tillage practices are performed in such a way that a vegetation strip around the streams is maintained, thus allowing the growth of sometimes dense riparian vegetation.

\subsection{Measurement devices and procedures}

One automatic weather station and three totalised pluviometers were installed in the watershed (Fig. 1) (Casalí et al., 2008). Air temperature, rainfall, relative air moisture, wind speed and direction, soil temperature, and solar radiation were recorded on a $10 \mathrm{~min}$ basis. Additionally, one hydrological station was installed at the watershed outlet (Fig. 1), where the water level and turbidity were recorded also every $10 \mathrm{~min}$. The discharge measurement device consisted of a triangular profile flat-V weir (Bos, 1978). This hydraulic structure was selected, among other reasons, because its design permitted the sediment to pass the control section.

Discharge was calculated from water level data, which were monitored using a pressure probe. Water samples were taken every $6 \mathrm{~h}$ from a hemispheric hollow, $0.66 \mathrm{~m}$ in diameter, made in the downstream face of the triangular profile flat-V weir. For this purpose, an automatic programmable sampler was used, consisting of $24,500 \mathrm{ml}$ bottles. Water samples were analysed following the standard methods for water quality parameters at the Agricultural Laboratory of the Department of Agriculture and Food of the Government of Navarre. Soil sediment concentration and dissolved nitrate and phosphate concentrations were determined, as well as other chemicals that are not dealt with in this paper (i.e.. sulphate, carbonate, bicarbonate, potassium, calcium, magnesium and sodium). The four samples collected each day were mixed together prior to analysis, to provide a representative daily average sample for determining sediment and nutrient concentrations (Isidoro et al., 2003).

The criteria for assessing rainfall events were the following: (i) a precipitation must accumulate a minimum of $0.2 \mathrm{~mm}$ to compute as a rainfall event and (ii) more than $6 \mathrm{~h}$ from the last rainfall event must pass before computing a new event.

Twenty eight hydrological parameters were defined and their corresponding values for a total of 131 rainfall/runoff events selected during 1996 and 2010 were determined (Table 2).

The rainfall-runoff events were characterised as follows. The conditions prior to the flood were described by the rainfall $1 \mathrm{~h}\left(\mathrm{aP}_{1}\right.$, $\mathrm{mm}), 24 \mathrm{~h}\left(\mathrm{aP}_{1 \mathrm{~d}}, \mathrm{~mm}\right), 7$ days $\left(\mathrm{aP}_{7 \mathrm{~d}}, \mathrm{~mm}\right)$, and 21 days $\left(\mathrm{aP}_{21 \mathrm{~d}}, \mathrm{~mm}\right)$ before the starting of the event. Similarly, the average discharge $1 \mathrm{~h}\left(\mathrm{aQ}_{1 \mathrm{~h}}, \mathrm{~m}^{3} \mathrm{~h}^{-1}\right)$ and $24 \mathrm{~h}\left(\mathrm{aQ}_{1 \mathrm{~d}}, \mathrm{~m}^{3} \mathrm{~h}^{-1}\right)$ before the beginning of the flood was also calculated for every rainfall-runoff. All these variables were meant to surrogate the antecedent average soil moisture value of the watershed. The rainfall causing every runoff event was characterised by the total water depth $(P, \mathrm{~mm})$, average intensity $\left(\mathrm{IP}, \mathrm{mm} \mathrm{h}^{-1}\right)$ and maximum rainfall in $10 \mathrm{~min}$, and $30 \mathrm{~min}\left(\mathrm{IP}_{10}\right.$ and $\mathrm{IP}_{30} \mathrm{~mm} \mathrm{~h}^{-1}$ ). The $\mathrm{EI}_{30}$ erosivity index (Wischmeier and Smith, 1978) was also determined.

The runoff was characterised by the total water depth $\left(Q_{t}, \mathrm{~mm}\right)$ and the direct runoff depth (Rd, $\mathrm{mm}$ ); where $R d$ is $Q_{t}$ after subtracting the baseflow. The contribution of the baseflow was determined by a linear baseflow separation (Hewlett and Hibbert, 1967). Additionally, the runoff peak was characterised by the average and maximum discharge of the flood: $Q_{m}$ and $Q_{\max }\left(\mathrm{m}^{3} \mathrm{~h}^{-1}\right)$, respectively. Also, the relationship between the maximum discharge and the initial discharge $\left(Q_{b}, \mathrm{~m}^{3} \mathrm{~h}^{-1}\right)$ prior to the event $\left(Q_{\max } / Q_{b}\right)$ was also calculated.
Similarly, the characteristics of sediment generated during each event, on a 10 min basis, were described using the average concentration $\left(\mathrm{SSC}_{m}, \mathrm{gl}^{-1}\right.$ ) and the maximum concentration ( $\mathrm{SSC}_{\max }, \mathrm{gl}^{-1}$ ) of the flood as well as the total sediment yield $\left(\mathrm{SS}_{t}, \mathrm{~kg} \mathrm{ha}^{-1}\right)$.

The classification of the floods in relation to their hysteretic loop, SSC-Q was made graphically according to some of the classes established by Williams (1989): clockwise, counter-clockwise and eight-shaped hysteretic loops; an undefined type was included, when the large scatter in the values hid the real shape of the hysteretic loop.

Multivariate analysis (CA and PCA) was made using the SPAD v. 6 software (Decisia, 1999). The vast majority of the researches using multivariate methods rely upon better known software, as SPSS. SPAD enables the researcher to analyse simultaneously both quantitative variables - as discharge, precipitation, sediments, and so $\mathrm{on}$ - and qualitative, as location of watershed, day of the week or month, abnormal weather conditions or year.

Building axes when using SPSS, for example, only take into consideration rating variables, but not the nominal. SPAD embeds both types of measurement scales. Axes are built on metric scales basis, as done by SPSS and related statistical packages, but SPAD enables the researcher to link qualitative and quantitative results. Qualitative variables are considered and named supplementary variables.

This feature is extremely useful for making links among the findings. Qualitative information, for example, the period in which data were collected, type of hysteretic loops or abnormal weather conditions can be included as data for analyses, as nominal variable in the spreadsheet, coded as one, two, three, ... according to the number of categories considered. Nominal variables have no quantitative contribution for building axes, but they have coordinates. When values of the coordinates are out of the interval of confidence, the analyst can identify some relations among the meaning of the axes and the qualitative variables embedded in them.

A cluster analysis of all the selected events as characterised above (Table 2) allows the assembling of events - without making a priori assumptions about them - based on the characteristics possessed by them. The resulting clusters of objects should then exhibit high internal homogeneity (within-cluster) and high external (between-cluster) heterogeneity. Unlike PCA (see below), the cluster analysis uses all the variances or information contained in the original dataset. CA can ultimately assist in the recognition of potentially meaningful patterns. In this study, a hierarchical agglomerative cluster analysis was performed on the data by means of Ward's method. This has a small space-distorting effect, uses more information on cluster contents than other methods and has been proved to be an extremely powerful grouping mechanism (Willet, 1987). As a measure of similarity, the Euclidean distances were applied.

The principal component analysis is designed to transform the original variables into new, uncorrelated variables called the principal components, which are linear combinations of the original variables. This technique provides information on the most meaningful parameters, which describes the whole dataset affording data reduction with a minimum loss of original information (Shrestha and Kazama, 2007). The variables sediment concentration and sediment yield were analysed separately as supplementary variables when the regression modelling failed or the models were very complex.

\section{Results and discussion}

Table 2 shows the mean value and dispersion of the 28 selected variables. The large dispersion of most of the variables points to the presence of temporal variations probably caused by climate factors. 
Table 2

Variables used to characterise the rainfall-runoff events selected from 1996 to 2010.

\begin{tabular}{|c|c|c|c|c|c|}
\hline Variable & Description (units) & Mean & Deviation & Min & Max \\
\hline $\mathrm{T}_{\text {HED }}$ & Time of direct runoff (min) & 1304 & 1530 & 0 & 8000 \\
\hline $\mathrm{aP}_{1}$ & Antecedent accumulated precipitation $1 \mathrm{~h}$ before the event (mm) & 0.02 & 0.06 & 0.00 & 0.36 \\
\hline $\mathrm{aP}_{1 \mathrm{~d}}$ & Antecedent accumulated precipitation 1 day before the event ( $\mathrm{mm}$ ) & 2.60 & 4.18 & 0.00 & 27.23 \\
\hline $\mathrm{aP}_{7 \mathrm{~d}}$ & Antecedent accumulated precipitation 7 days before the event ( $\mathrm{mm}$ ) & 22.04 & 19.77 & 0.00 & 91.60 \\
\hline $\mathrm{aP}_{21 \mathrm{~d}}$ & Antecedent accumulated precipitation 21 days before the event ( $\mathrm{mm}$ ) & 52.71 & 36.26 & 0.53 & 195.00 \\
\hline $\mathrm{P}$ & Accumulated precipitation during the event $(\mathrm{mm})$ & 23.22 & 15.88 & 5.80 & 102.12 \\
\hline IP & Mean precipitation intensity $\left(\mathrm{mm} \mathrm{h}^{-1}\right)$ & 0.91 & 0.94 & 0.06 & 4.61 \\
\hline $\mathrm{IP}_{10}$ & Maximum precipitation intensity in $10 \mathrm{~min}\left(\mathrm{~mm} \mathrm{~h}^{-1}\right)$ & 13.58 & 13.81 & 0.40 & 62.58 \\
\hline $\mathrm{IP}_{30}$ & Maximum precipitation intensity in $30 \mathrm{~min}\left(\mathrm{~mm} \mathrm{~h}^{-1}\right)$ & 8.70 & 7.75 & 1.10 & 46.36 \\
\hline $\mathrm{EI}_{30}$ & $\mathrm{EI}_{30}$ erosivity jndex $\left(\mathrm{MJ} \mathrm{mm}\right.$ year $\left.{ }^{-1} \mathrm{~h}^{-1} \mathrm{ha}^{-1}\right)$ & 35.64 & 55.82 & 0.70 & 445.79 \\
\hline$Q_{b}$ & Base discharge before the event $\left(\mathrm{m}^{3} \mathrm{~s}^{-1}\right)$ & 0.023 & 0.036 & 0.000 & 0.199 \\
\hline $\mathrm{aQ}_{1 \mathrm{~h}}$ & Antecedent discharge $1 \mathrm{~h}$ before the event $\left(\mathrm{m}^{3} \mathrm{~s}^{-1}\right)$ & 0.024 & 0.037 & 0.000 & 0.202 \\
\hline$a Q_{1 d}$ & Antecedent discharge 1 day before the event $\left(\mathrm{m}^{3} \mathrm{~s}^{-1}\right)$ & 0.027 & 0.050 & 0.000 & 0.323 \\
\hline$Q_{t}$ & Total runoff $(\mathrm{mm})$ & 6.93 & 12.73 & 0.00 & 100.80 \\
\hline $\mathrm{Fb}$ & Total base flow (mm) & 5.49 & 5.82 & 0.09 & 40.45 \\
\hline Rd & Total direct runoff $(\mathrm{mm})$ & 3.69 & 7.95 & 0.00 & 60.35 \\
\hline$Q_{m}$ & Mean discharge $\left(\mathrm{m}^{3} \mathrm{~s}^{-1}\right)$ & 0.088 & 0.126 & 0.000 & 0.915 \\
\hline$Q_{\max }$ & Maximum discharge $\left(\mathrm{m}^{3} \mathrm{~s}^{-1}\right)$ & 0.264 & 0.592 & 0.000 & 4.355 \\
\hline$Q_{\max } / P$ & Relation between maximum discharge and precipitation & 0.01 & 0.01 & 0.00 & 0.06 \\
\hline$Q_{\max } / Q_{b}$ & Relation between maximum and base discharge & 180.52 & 1561.94 & 0.00 & $16,462.10$ \\
\hline $\mathrm{Rd} / P$ & Relation between direct runoff and precipitation & 0.12 & 0.14 & 0.00 & $\hat{0.66}$ \\
\hline$t_{p}$ & Peak time of runoff hydrograph (min) & 1019 & 861 & 180 & 4140 \\
\hline$t_{\mathrm{dif}}$ & Time between maximum discharge and sediment concentration (min) & 139 & 559 & -1400 & 2880 \\
\hline $\mathrm{SSC}_{m}$ & Mean suspended sediment concentration $\left(\mathrm{g} \mathrm{l}^{-1}\right)$ & 0.096 & 0.136 & $\wedge \quad 0.000$ & 0.590 \\
\hline $\mathrm{SSC}_{\max }$ & Maximum suspended sediment concentration $\left(\mathrm{g} \mathrm{l}^{-1}\right)$ & 0.429 & 0.584 & 0.000 & 3.600 \\
\hline $\mathrm{SS}_{t}$ & Total sediment discharge $\left(\mathrm{kg} \mathrm{ha}^{-1}\right)$ & 21.33 & 75.73 & 0.00 & 732.87 \\
\hline $\mathrm{CN}$ & Curve number & 24.42 & 28.05 & 0.00 & 98.41 \\
\hline $\mathrm{H}_{\Lambda}^{\mathrm{a}}$ & Type of hysteretic loop & $\bar{\wedge}$ & - & - & - \\
\hline
\end{tabular}

a Categorical variables.

In fact, the rainfall pattern is typical for humid Mediterranean climates (Fig. 2). The intra-annual variability of the precipitation was high. The accumulated annual rainfall ranged from a maximum of $1231 \mathrm{~mm}$ (agricultural year 2006-2007) to a minimum of $482 \mathrm{~mm}$ (agricultural year 2001-2002), with an average value of $828 \mathrm{~mm}$.

According to the $\mathrm{EI}_{30}$ rainfall erosivity index (Morgan, 2005), more than $80 \%$ of the rain events recorded throughout the year had a (very) low erosivity $\left(\mathrm{EI}_{30}<100 \mathrm{~J} \mathrm{~mm} \mathrm{~m}^{-2} \mathrm{~h}^{-1}\right)$. In contrast, just a few rain events had a (very) high erosivity, i.e., 2 or 3 orders of magnitude higher than the one above. Normally, high erosive rainfalls were very scarce during winter and early spring.

The intra-annual variability of the runoff, on the other hand, was also high with the maximum and minimum variability in winter, and in spring, respectively (Fig. 2). Accumulated annual discharge ranged between 100 and $396 \mathrm{~mm}$ with average values of 229 .

With regard to sediment yield (Fig. 3), 50\% of the events was responsible for 70 tonnes of exported sediment, whilst the other

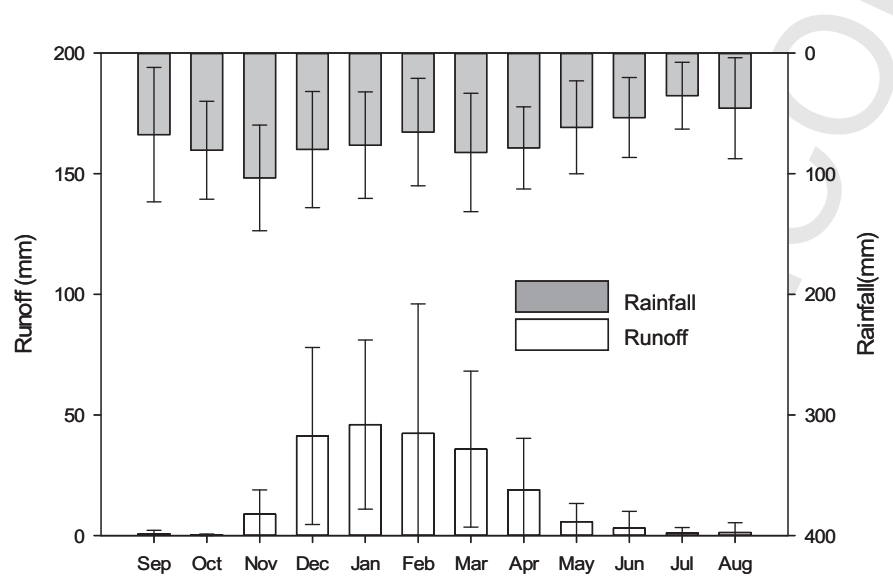

Fig. 2. Monthly average rainfall and runoff at Laxtaga (1996-2010). Vertical bars are standard deviation.
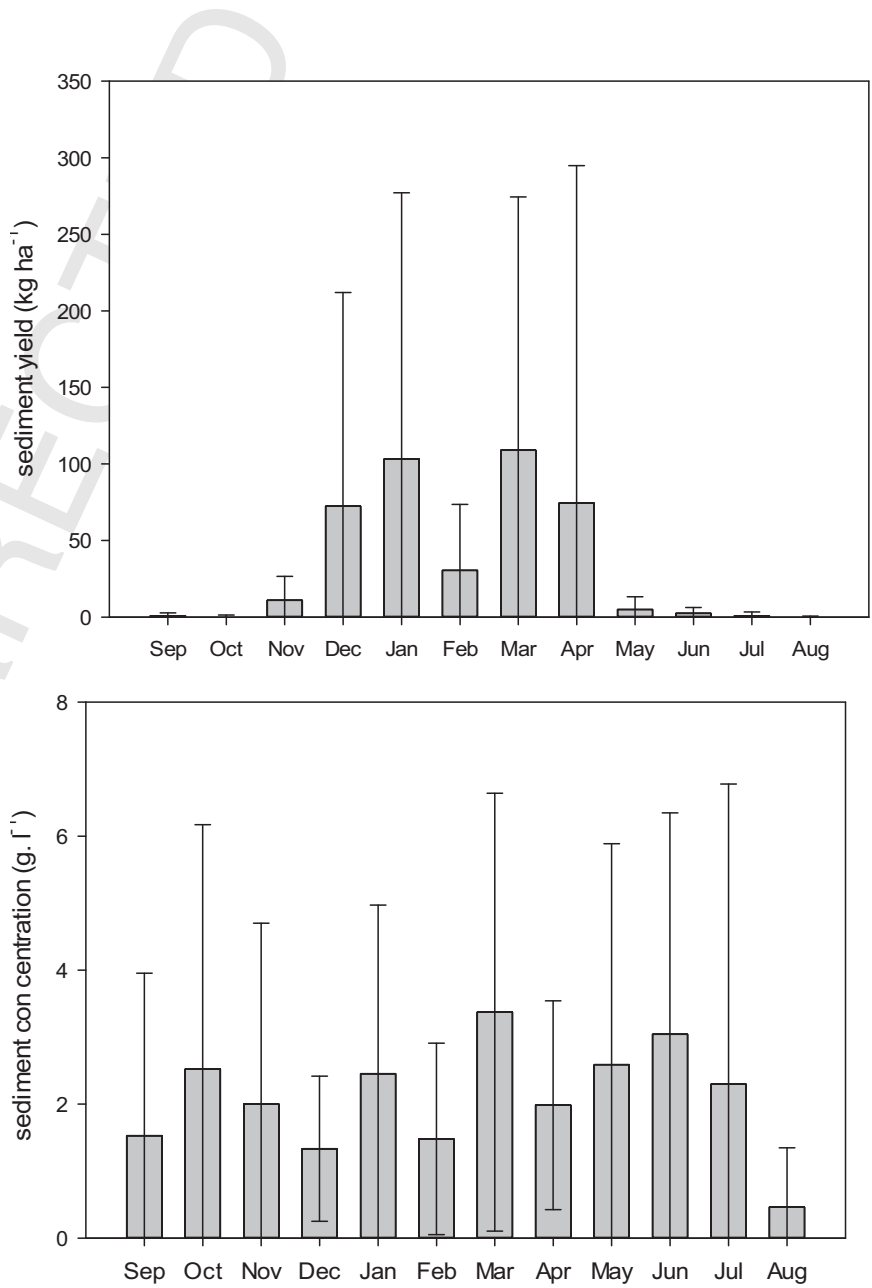

Fig. 3. Monthly average sediment yield and sediment concentration values $(1996-2010)$ at Laxtaga watershed. Vertical bars are standard deviation. 
half generated more than 400 tonnes; but with just 4 events producing ca. 270 tonnes. This indicates an irregular behaviour also in sediment production in the watershed. Overall, and for the last 15 years, the mean annual sediment yield and sediment concentration were $400 \mathrm{~kg} \mathrm{ha}^{-1}$ and $128 \mathrm{mg} \mathrm{l}^{-1}$, respectively.

\subsection{Cluster analysis}

Cluster analysis was carried out using all the defined variables (Table 2). There were no clusters encompassing events from a single year of the sampling period, which indicates that the interannual variability throughout the study period was negligible. In other words, there were not any unusual - hydrologically speaking - year(s) throughout the monitored period (i.e., 1996-2010) that could have somewhat biased the overall analysis.

In contrast, a clear intra-annual variability was confirmed. More precisely, the CA results, at a long Euclidian distance, in a division of the data into two groups (not shown) comprising around half of the total events each. One of the groups - including events from November to April - was characterised by a significant hydrological response (i.e., increase in the peak flow) to any precipitation. Conversely, the second group comprises those events that, occurring from May to October, are associated with a very small hydrological response. In fact, some events that occurred from May to October generated (almost) no runoff: a null hydrological response. This hydrological response is reflected in the relatively large $Q_{\max } / P$ ratio ( 0.017 on average) of the first group in comparison to that of the second group ( 0.001 on average) (García-Ruiz et al., 2005). In addition, mean runoff coefficients in the two groups were, respectively, $19 \%$ and $0.26 \%$. Moreover, the average runoff depth in the dry season was only $0.3 \mathrm{~mm}$ whilst in the wet season it rose to ca. $13 \mathrm{~mm}$.

García-Ruiz et al. (2005), in a small Mediterranean watershed, also reported rapid and low runoff responses to rainfall according to the $Q_{\max } / P$ relationship. However, they observed that their watershed significantly reacted to almost any rainstorms, even during the dry season, which is not our case, as already pointed out.

\subsection{Principal component analysis}

In order to analyse the main factors controlling suspended sediment concentration and yield in the watershed, a PCA was performed. To do that, and in agreement with Zabaleta et al. (2007), a number of events that generated (almost) no runoff (and hence practically no sediment) at the watershed outlet, were discarded from the analysis; i.e., those events that occurred mostly during the dry season (see above). In addition, a number of events were also discarded due to a malfunction of the sampler that registered no sediment at the watershed outlet. Finally, a total of 65 events remained for analysis. In addition, sediment concentration and sediment yield were consequently used as supplementary variables. Only axes (factors) presenting a significant loading of the supplementary variables were considered for further analyses. After preliminary trials and for an overall improvement in the performance of the PCA, several of the original variables were filtered out (cf. Table 3).

From the PCA (Table 3), it could be observed that factors 1 and 2 not only explained a large part of the total variance (29.3 and 19.1, respectively) but, and most important for our analysis, they are the only factors presenting significant correlations with sediment yield (factor 1 ) and - but to a lesser extent - with sediment concentration (factor 2). The other factors were then discarded for further analysis.

Factor 1 is, in turn, highly participated by variables related to runoff $\left(Q_{t}, R d, Q_{m}, Q_{\max }\right.$; see Table 2 for legend) and to the antecedent (soil moisture) conditions of the event (Table 3 ). Antecedent discharge $\left(\mathrm{aQ}_{1 \mathrm{~h}}, \mathrm{aQ}_{1 \mathrm{~d}}\right)$ appears as being a better
Table 3

Loading of the experimental variables on the first two PCs for 65 events.

\begin{tabular}{llll}
\hline $\begin{array}{l}\text { Number of } \\
\text { component }\end{array}$ & Eigenvalue & Percentage & $\begin{array}{l}\text { Cumulated } \\
\text { Percentage }\end{array}$ \\
\hline 1 & 5.8693 & 29.35 & 29.35 \\
2 & 3.8183 & 19.09 & 48.44 \\
3 & 3.4145 & 17.07 & 65.51 \\
4 & 1.5219 & 7.61 & 73.12 \\
5 & 1.2064 & 6.03 & 79.15 \\
6 & 1.0331 & 5.17 & 84.32
\end{tabular}

Active variables - factors correlations

\begin{tabular}{|c|c|c|}
\hline Variable & Axis 1 & Axis 2 \\
\hline$T_{\mathrm{HED}}$ & 0.20 & -0.60 \\
\hline $\mathrm{aP}_{1}$ & 0.00 & ${ }^{\wedge}-0.08$ \\
\hline $\mathrm{aP}_{1 \mathrm{~d}}$ & 0.21 & 0.14 \\
\hline $\mathrm{aP}_{7 \mathrm{~d}}$ & 0.34 & 0.03 \\
\hline $\mathrm{aP}_{21 \mathrm{~d}}$ & 0.25 & 0.00 \\
\hline$P$ & 0.65 & 0.06 \\
\hline IP & -0.01 & 0.85 \\
\hline $\mathrm{IP}_{10}$ & $\stackrel{\wedge}{-0.09}$ & 0.85 \\
\hline $\mathrm{IP}_{30}$ & -0.05 & 0.90 \\
\hline $\mathrm{EI}_{30}$ & 0.20 & 0.69 \\
\hline $\mathrm{aQ}_{1 \mathrm{~h}}$ & 0.63 & -0.04 \\
\hline $\mathrm{aQ}_{1 \mathrm{~d}}$ & 0.62 & ${ }^{\wedge}-0.03$ \\
\hline$Q_{t}$ & 0.95 & -0.07 \\
\hline $\mathrm{Rd}$ & 0.95 & 0.04 \\
\hline$Q_{m}$ & 0.88 & 0.22 \\
\hline$Q_{\max }$ & 0.90 & 0.25 \\
\hline$Q_{\max } / Q b$ & $\Lambda^{-0.01}$ & 0.00 \\
\hline $\mathrm{Rd} / P$ & ${ }^{\wedge} 0.87$ & -0.06 \\
\hline$t_{p}$ & 0.45 & -0.55 \\
\hline$t_{\text {dif }}$ & -0.03 & 0.53 \\
\hline \multicolumn{3}{|c|}{ Supplementary variables - factors correlations } \\
\hline Variable & Axis 1 & Axis 2 \\
\hline $\mathrm{SSC}_{m}$ & 0.08 & 0.26 \\
\hline $\mathrm{SS}_{t}$ & 0.70 & 0.04 \\
\hline
\end{tabular}

surrogate (with higher loading) than antecedent precipitation (e.g., $\mathrm{aP}_{1}, \mathrm{aP}_{1 \mathrm{~d}}$ ) (Table 3 ). In fact, runoff can be largely conditioned by the soil moisture content prior to the event. The increment in soil water content reduces, in turn, the infiltration capacity of the soils and its capability to store new rainfall water, as reflected in many physically based hydrological models (Bronstert et al., 1998). This saturation overland flow is predominant in our watershed during winter (Casalí et al., 2008). In line with that, Van Dijk and Kwaad (1996) observed from experiments carried out in various small agricultural watersheds with loess-derived soils that much runoff occurred in winter, concluding that soil moisture storage capacity may be just as important for runoff generation as infiltration capacity. In addition, Seeger et al. (2004) and Garcj́a-Ruiz et al. (2005) observed that the average soil moisture was the main factor controlling the runoff generation and sediment transport processes in small Mediterranean watersheds.

Interestingly, sediment yield as mentioned above is more related to the soil conditions than to features related to the erosive power of the rainfall - see the small loading of these last variables in factor 1 . The most erosive rainfall events normally occurred during the dry period; they were of a short duration and then the rainfall volume was (almost) totally incorporated into the soil. Therefore, Hortonian flow was very small and infrequent during the dry period, and, hence, the soil particles eroded by the rainfall were to a large extent unable to reach the watershed outlet due to the small transporting capacity of the flow at that time. The highly scant generation of Hortonian flow during the dry period was reflected in field experiments carried out by the authors in August 2009, using a rain simulator over a $1 \mathrm{~m}^{2}$ plot: for instance ca. $30 \mathrm{~mm} \mathrm{~h}^{-1}$ of rainfall during more than $2 \mathrm{~h}$ generated 
practically no runoff. Additionally, the large infiltration capacity of the soil matrix when dry is believed to be increased to some extent by the transport capacity of the macropores/cracks formed as a consequence of soil shrinkage. Similarly, in some Mediterranean middle mountain watersheds, during summer time, Gallart et al. (1998) recorded a precipitation of $50 \mathrm{~mm}$ in $24 \mathrm{~h}$ that generated no runoff either.

On the other hand, sediment concentrations were irregular throughout the year so that no clear pattern at a seasonal or event scale was observed. Steegen et al. (2000) reported a decrease in the suspended sediment concentration during summer in a small agricultural watershed. This was attributed to the denser vegetation cover during the summer period that protected the soil against erosive rainfall and acted also as sediment traps for sediment produced upslope. In contrast, Kwaad (1991) measured a much higher sediment concentration during summer than during winter in fallow plots. He attributed this to the higher rainfall intensities during the summer period, but the lower resistance of a dry soil to runoff detachment may also have played a role (Govers et al., 1990). In accordance with Steegen et al., one might also have expected certain sediment concentration depletion during the dry season in our case. However, the degree of surface cover protection in Laxtaga watershed throughout the year js - though relatively high during summer - spatially and temporally variable for several reasons. First, because of the individual management and land use of the numerous agricultural plots conforming the watershed. Secondly, the degree of protection of riparian and stream channels given by the natural vegetation is along the year somewhat different than that of the agricultural area. All these reasons might to some extent explain the aforementioned irregular behaviour of sediment concentration dynamics.

Furthermore, sediment concentration unlike sediment yield did not show any significant correlation with discharge variables but only a moderate one with features related to rainfall erosivity (e.g., $\mathrm{IP}_{30}$ and $\mathrm{EI}_{30}$ in factor 2 of Table 3). The latter fact points out the importance of splash erosion on sediment generation (Lorente et al., 2000).

Neither was any correlation between sediment concentration and discharge variables observed by Zabaleta et al. (2007) in a small forested watershed. They explain this as being a consequence of a small amount of sediment available for transport during events as sediment concentration cannot increase at the same magnitude as discharge does, thus leading to a sort of dilution, and, hence, to a poor correlation between both variables. This low sediment availability was in line with the similarly small mean sediment yield $\left(0.15\right.$ tonnes $\left.^{-1}\right)$ recorded in their forested watershed, which was 3 times lower than that of the Laxtaga watershed.

However, in our case, the above paradox can be understood for opposite reasons. That is, sediment supply throughout the year in the Laxtaga watershed may be large enough to maintain sediment concentration roughly constant along a wide range of runoff volume. Precisely, for all the events, a slight increment in maximum sediment concentration with peak discharge $\left(Q_{\max }\right)$ was found (Fig. 4). But if the hypothesis of Zabaleta et al. also applies in our situation, the last figure (Fig. 4) should have reflected a decreasing tendency (by dilution effect) rather than an increasing one. In line with our findings, Mateos and Giráldez (2005) demonstrated that soil erosion rates, and, consequently, suspended sediment, can be high even due to the action of small runoffs flowing over very gentle terrains. In addition, large concentrations of suspended sediment in small floods were also reported by Nadal-Romero et al. (2008).

In fact, and as Lorente et al. (2000) indicate, sediment concentration is not necessarily highly linked only to runoff features since - for instance - peak discharges and peak sediment rarely meet in the course of an event.

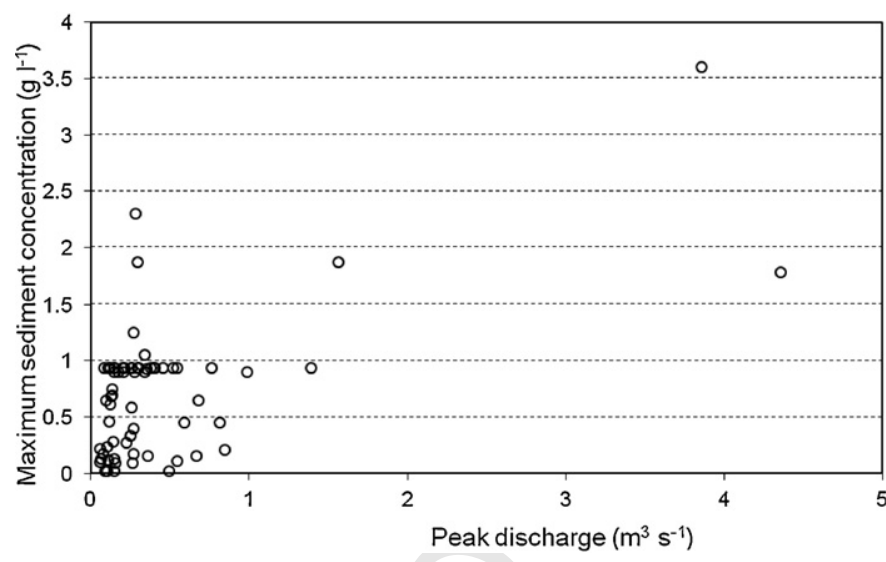

Fig. 4. Maximum sediment concentration and peak discharge relationship for all the events.

\subsection{Hysteresis analysis}

Even though the hysteresis loops variable was filtered out for a better performance of the PCA (see above), the SSC-Q relationship for each event was nonetheless analysed. Most of the events (45) presented clockwise hysteresis (Fig. 5), whilst counterclockwise and eight-shape types were determined only twice in each case, for which reason these two were considered to be unrepresentative of the general behaviour of the watershed. However, 16 events were not considered in the analysis due to the extreme complexity of their hydrological response, that made the
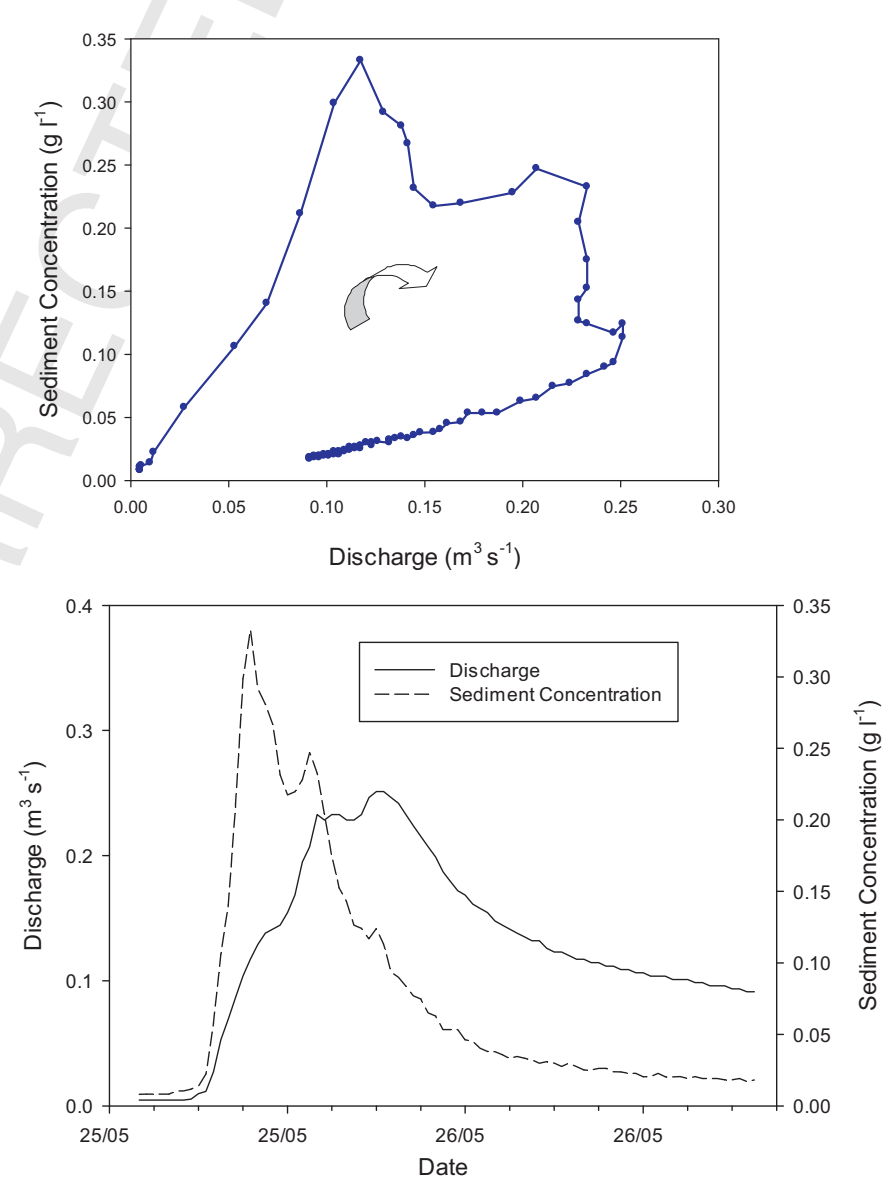

Fig. 5. Upper figure: example of clockwise hysteretic loops corresponding to the event of 25/05/08. Lower figure: hydrograph and sedigraph. 
determination of the hysteretic loops too uncertain. This is not very surprising considering the great variability observed in suspended sediment concentration throughout different time scales (Fig. 3). Since small watersheds are more sensitive to inputs of sediment from local sources (Rodríguez-Blanco et al., 2010), the variability in the suspended sediment-discharge relationship is normally higher in small watersheds than in large ones (Klein, 1984). This then often hampers the correct definition of hysteretic loops in the SSC-Q relationship.

Although clockwise is a very common and well known type of hysteresis (Williams, 1989; Seeger et al., 2004), the hydrological interpretation of the hysteresis phenomenon is, in general, not straightforward because of the lumped nature of this approach (Slattery and Burt, 1997). Normally, clockwise hysteresis may result from any of the four following causes. First, the sediment supply is coming mainly and rapidly from the channel bed or the channel bank, j.e., the 'bulldozer' effect (Regües et al., 2000). Secondly, this extra sediment load is a consequence of the removal of sediment produced in the interstorm period by the first flush of water (e.g., Gregory and Walling, 1973). A third possible reason is that runoff coming from the outer edges of the watersheds, and then arriving at the outlet at the end of the event, has a lower sediment load since the probability of deposition increases with the travel distance (Steegen et al., 2000). Finally, clockwise hysteresis may also occur because of the increment in the baseflow during the recession limb of the hydrograph, that consequently results in a decrease in sediment concentration (Becht, 1989).

Our field observations have not revealed any noticeable geomorphological activity in the main channels, so that the first reason mentioned above for the occurrence of clockwise hysteresis (i.e., bed/bank channel erosion) could be considered to be unimportant. On the other hand, a negligible dilution effect of baseflow on sediment concentration was determined as follows. In a number of events the sediment concentration before and after the inflection point on the falling limb were found and this point is supposed to represent the end of the direct runoff (Molnár, 1970). After the inflection point, when the baseflow then mainly contributes to total runoff, the average change in sediment concentration was very small, less than $5 \%$.

As indicated by Williams (1989) and confirmed elsewhere (e.g., Regües et al., 2000; Seeger et al., 2004), the rapid increase in sediment concentration at the beginning of the flood and then decreasing before the discharge (Fig. 5) suggests a rapid displacement of a limited amount of sediment. Therefore, the runoff generation, and, hence, sediment transport, are limited mainly to areas near the channel.

However, the infrequent appearance of counter-clockwise loop events indicates that, eventually, the runoff and sedimentcontributing areas are extended to the whole watershed (Seeger et al., 2004) so that most of the watershed area is then hydrologically connected and contributing to runoff and sediment production.

To make a comparison between events showing a clockwise hysteresis a normalised hysteresis index was calculated (Langlois et al., 2005) based on the determination of the area comprised between the rising and the falling limb of the sediment-flow graph. In line with all the above, a roughly constant value of the hysteresis index was observed throughout the year, which confirmed that the availability of sediments in the watershed does not follow a clear seasonal pattern.

\section{Conclusions}

This paper evidences the hydrological behaviour of a typical Mediterranean agrarian watershed in terms of discharge and sediment response to rainfall events. In this, the antecedent (season-dependent) condition of the flow is of paramount importance.

In the Laxtaga watershed, during the wet period (November-April) the high soil moisture content of the soil leads to a relative rapid generation of overland flow in almost any rainstorm events. In contrast, throughout the dry period (June-October), when more intense rainfalls occurred, they were, however, hardly able to generate any Hortonian flow. In fact, in the heart of the summer, and soon after the occurrence of (intense) precipitations, no runoff at all is frequently recorded at the watershed outlet. This can be explained by the dramatic increase in the infiltration capacity of the soil matrix when dry. Besides, the preferential flow paths through macropores may also play a key role.

As regards sediment production, during winter (wet period), the scant vegetation cover facilitates a significant sediment detachment and transport by the prompt overland flow.

On the other hand, during the dry period, a certain amount of sediment detached by the erosive rainfalls is to be expected. However, much of this sediment remains within the watershed as a consequence of the generally limited transport capacity of the flow (small runoff) at that time.

Most of the eroded sediment seems to come from sources near the stream channel, but, eventually, sediment sources are widespread throughout the watershed. However, due to the lumped nature of the processes involved, the validation of these interpretations would require a field monitoring of the soil hydrological conditions within the watershed.

In the case of any lack of direct values of soil moisture content, the discharge recorded at the watershed outlet up to $\hat{\Lambda}_{1} \mathrm{~h}$ prior to the flood appears to be a very good surrogate for antecedent soil humidity.

Our findings corroborate the importance of maintaining dense channel vegetation in order to trap sediments; this would also help to get satisfactory standard of water quality, j.e., water with low levels of agrochemicals. Moreover, it is recommended that land management should allow vegetation to grow along streams. All this would be especially important in those watersheds which morphological and topographic characteristics - e.g., with a more circular shape and flatter surface than the present one - may afford a rapid removal of precipitations promoting then large and erosive peak discharges. These last types of watersheds are also typical of our region (Casalí et al., 2008).

\section{Acknowledgements}

This study was partly funded by the Spanish Government's National Scientific Research, Development and Technological Innovation Plan, both project code CGL2007-63453 and project code CGL2011-24336. The authors also acknowledge the generous contribution of the Department of Rural Development and Environment of the Government of Navarre (Spain).

\section{References}

Baca, P., 2008. Hysteresis effect in suspended sediment concentration in the Rybárik basin, Slovakia. Hydrological Sciences Journal 53 (1), 224-235.

Becht, M., 1989. Suspended load yield of a small alpine drainage basin in upper Bavaria. Landforms and landform evolution in West Germany. Catena 15 (Suppl.), 329-342.

Bos, M.G., 1978. Discharge Measurement Structures. International Institute for Land Reclamation and Improvement (ILRI), Wageningen, The Netherlands, 464 pp.

Bronstert, A., Glüsing, B., Plate, E., 1998. Physically-based hydrological modelling on the hillslope and micro-catchment scale: examples of capabilities and limitations. In: Hydrology, Water Resources and Ecology in Headwaters (Headwater'98 Conference). IAHS Publ. IAHS, Meran/Merano, pp. 207-215.

Casalí, J., Gastesi, R., Álvarez-Mozos, J., De Santisteban, L.M., Del Valle de Lersundi, J., Giménez, R., Larrañaga, A., Goñi, M., Agirre, U., Campo, M.A., López, J.J., Donézar, 
M., 2008. Runoff, erosion, and water quality of agricultural watersheds in central Navarre (Spain). Agricultural Water Management 95, 1111-1128.

Casalí, J., Giménez, R., Díez, J., Álvarez-Mozos, J., Del Valle de Lersundi, J., Goñi, M., Campo, M.A., Chahor, Y., Gastesi, R., López, J., 2010. Sediment production and water quality of watersheds with contrasting land use in Navarre (Spain). Agricultural Water Management 97 (10), 1683-1694.

Decisia, 1999. Spad. Manual de Prise en main, Pantin Cedex.

EEA (European Environment Agency), 2005 . The European Environment $\bar{\Lambda}$ State and Outlook 2005. EEA, Copenhagen.

Fang, H.Y., Cai, Q.G., Chen, H., Li, Q.Y., 2008. Temporal changes in suspended sediment transport in a gullied loess basin: the lower Chabagou Creek on the Loess Plateau in China. Earth Surface Processes and Landforms 33 (13), 1977-1992.

Gallart, F., Latron, J., Regüés, D., 1998. Hydrological and sediment processes in the research catchments of Vallcebre (Pyrenees). In: Boardman, J., Favis-Mortlock, D. (Eds.), Modelling Erosion by Water. NATO-ASI Series $1 \bar{\wedge}-55$. Springer, Berlin, pp. 503-511.

García-Ruiz, J.M., Arnáez, J., Beguería, S., Seeger, M., Martí-Bono, C., Regüés, D., Lana-Renault, N., White, S., 2005. Runoff generation in an intensively disturbed, abandoned farmland catchment, central Spanish pyrenees. Catena 59 (1), 79-92.

Giménez, R., Casalí, J., Díez, J., 2009. Effect of sediments generated by rill erosion on soil hydrology at small spatial scale. European Geosciences Union, Vienna, Austria. Geophysical Research Abstracts 11, EGU2009-EGU2010.

Gobierno de Navarra, 1997. Mapa geológico de Navarra 1:200.000. Gobierno de Navarra, Departamento de Obras Públicas, Transportes y Comunicaciones, Pamplona, Spain.

Gobierno de Navarra, 2001. Estudio Agroclimático de Navarra (CD). Gobierno de Navarra, Departamento de Agricultura, Ganadería y Alimentación, Servicio de Estructuras Agrarias, Pamplona, Spain.

Govers, G., Everaert, W., Poesen, J., Rauws, G., De Ploey, J., Lautridou, J.P., 1990. A long-flume study of the dynamic factors affecting the resistance of a loamy soil to concentrated flow erosion. Earth Surface Processes and Landforms 15, 313-328.

Gregory, K.J., Walling, D.E., 1973. Drainage Basin Form and Process. A Geomorphological Approach. London, Edward Arnold.

Hewlett, J.D., Hibbert, A.R., 1967. Factors affecting the response of small watersheds to precipitation in humid areas. In: Sopper, W.E., Lull, H.W. (Eds.), Forest Hydrology. Pergamon Press, New York, pp. 275-290.

Hillel, D., 1980. Applications of Soil Physics. Academic Press, New York, p. 385.

Isidoro, D., Quílez, D., Aragüés, R., 2003. Sampling strategies for the estimation of salt and nitrate loads in irrigation return flows: La Violada Gully (Spain) as a case study. Journal of Hydrology 271, 39-51.

Jansson, M.B., 2002. Determining sediment source areas in a tropical river basin, Costa Rica. Catena 47 (1), 63-84.

Klein, M., 1984. Anti clockwise hysteresis in suspended sediment concentration during individual storms: Holbeck catchment; Yorkshire, England. Catena 11 (2-3), 251-257.

Kwaad, F.J.P.M., 1991. Summer and winter regimes of runoff generation and soil erosion on cultivated loess soils (The Netherlands). Earth Surface Processes and Landforms 16, 653-662.

Lambrakis, N., Antonakos, A., Panagopoulos, G., 2004. The use of multicomponent statistical analysis in hydrogeological environmental research. Water Research 38 (7), 1862-1872.

Langlois, J.L., Johnson, D.W., Mehuys, G.R., 2005. Suspended sediment dynamics associated with snowmelt runoff in a small mountain stream of Lake Tahoe (Nevada). Hydrological Processes 19, 3569-3580.

Lorente, A., Mârtı-Bono, C., Beguerı, S., Arnaez, J., Garcia-Ruiz, J.M., 2000. La exportacion de sedimento en suspension en una cuenca de campos abandonados, Pirineo Central Español. Cuaternario y Geomorfologı 14, 21-34.

Mateos, L., Giráldez, J.V., 2005. Suspended load and bed load in irrigation furrows. Catena 64, 232-246.
Molnár, L., 1970. Determination of the direct runoff of hydrographs. Journal of Hydrology and Hydromechanics 18 (2), 143-155.

Montgomery, D.R., 2007. Soil erosion and agricultural sustainability. Proceedings of the National Academy of Sciences of the United States of America 104 (33), $13268-13272$.

Morgan, R.P.C., 2005. Soil Erosion and Conservation, 3rd ed. Blackwell Publishing.

Nadal-Romero, E., Regüés, D., Latron, J., 2008. Relatiônships among rainfall, runoff, and suspended sediment in a small catchment with badlands. Catena 74 (2), $127-136$.

Raux, J., Copard, Y., Laignel, B., Fournier, M., Masseï, N., 2011. Classification of worldwide drainage basins through the multivariate analysis of variables controlling their hydrosedimentary response. Global and Planetary Change 76, 117-127.

Regües, D., Balasch, J.C., Castelltort, X., Soler, M., Gallart, F., 2000. Relación entre las tendencias temporales de producción y transporte de sedimentos y las condiciones climáticas en una pequeña cuenca de montaña mediterránea (Vallcebre Pirineos Orientales). Cuadernos de Investigación Geográfica 26, 41-65.

Rodríguez-Blanco, M.L., Taboada-Castro, M.M., Taboada-Castro, M.T., 2010. Factors controlling hydro-sedimentary response during runoff events in a rural catchment in the humid Spanish zone. Catena 82 (3), 206-217.

Salant, N.L., Hassan, M.A., Alonso, C.V., 2008. Suspended sediment dynamics at high and low storm flows in two small watersheds. Hydrological Processes 22 (11), 1573-1587.

Seeger, M., Errea, M.P., Beguerı, S., Arnáez, J., Martı, C., Garcı-Ruiz, J.M., 2004 Catchment soil moisture and rainfall characteristics as determinant factors for discharge/suspended sediment hysteretic loops in a small headwater catchment in the Spanish Pyrenees. Journal of Hydrology 288, 299-311.

Shrestha, S., Kazama, F., 2007. Assessment of surface water quality using multivariate statistical techniques: a case study of the Fuji river basin, Japan. Environmental Modelling and Software 22 (4), 464-475.

Singh, K.P., Malik, A., Mohan, D., Sinha, S., 2004. Multivariate statistical techniques for the evaluation of spatial and temporal variations in water quality of Gomti River (India) - a case study. Water Research 38 (18), 3980-3992.

Slattery, M.C., Bûrt, T.P., 1997. Particle size characteristics of suspended sediment in hillslope runoff and stream flow. Earth Surface Processes and Landforms 22 , 705-719.

Soler, M., Latron, J., Gallart, F., 2008. Relationships between suspended sediment concentrations and discharge in two small research basins in a mountainous Mediterranean area (Vallcebre, Eastern Pyrenees). Geomorphology 98 (1-2), $143-152$.

Steegen, A., Govers, G., Nachtergaele, J., Takken, I., Beuselinck, L., Poesen, J., 2000. Sediment export by water from an agricultural catchment in the Loam Belt of central Belgium. Geomorphology 33 (1-2), 25-36.

Van Dijk, P.M., Kwaad, F.J.P.M., 1996. Runoff generation and soil erosion in small agricultural catchments with loess-derived soils. Hydrological Processes $\Lambda^{10}$ 1049-1059.

Vega, M., Pardo, R., Barrado, E., Debán, L., 1998. Assessment of seasonal and polluting effects on the quality of river water by exploratory data analysis. Water Research 32 (12), 3581-3592.

Willet, P., 1987. Similarity and Clustering in Chemical Information Systems. Research Studies Press, Wiley, New York.

Williams, G.P., 1989. Sediment concentration versus water discharge during single hydrologic events in rivers. Journal of Hydrology 111 (1-4), 89-106.

Wischmeier, W.H., Smith, D.D., 1978. Predicting rainfall erosion losses. In: Agriculture Handbook No. 537. United States Department of Agriculture, Washington, DC, USA, 58 pp.

Zabaleta, A., Martínez, M., Uriarte, J.A., Antigüedad, I., 2007. Factors controlling suspended sediment yield during runoff events in small headwater catchments of the Basque Country. Catena 71 (1), 179-190. 